\title{
Investigation of vertical mass changes in the south of Izmir (Turkey) by monitoring microgravity and GPS/GNSS methods
}

\author{
Oya Pamukçu, Tolga Gönenç*, Ayça Çirmik, Petek Sindirgi, \\ İLKNUR KAFTAN and ÖZER AKDEMIR \\ Dokuz Eylul University, Department of Geophysical Engineering, Tinaztepe Campus, Buca, Izmir, Turkey. \\ ${ }^{*}$ Corresponding author. e-mail: tolga.gonenc@deu.edu.tr
}

The monitoring of gravity changes in a region enables the investigation of regional structural elements depending upon the changes in load compensation. This method, preferred in recent years, has yielded good results from different parts of the world for determination of the deformation at fields. With the addition of GPS/GNSS monitoring to microgravity studies, the mass changes within the crust in vertical directional movements of a region can be estimated. During GPS/GNSS monitoring and microgravity studies, it was found that the behaviour of vertical directions of Izmir and the surrounding areas, indicate an active tectonic regime and high seismic activity, especially since 2000. As a result, regions considered to have a mass change in vertical direction were determined by 3-year measurements and it was found that they were consistently highly seismic.

\section{Introduction}

Microgravity is a geophysical method defining density changes under the surface. The method is affected directly by density distribution under the surface, especially the existence of the cavities creating a mass loss in proportion to surrounding environment. This also enables a convenient definition of subsurface environment (Butler 1984; Ioane and Ion 2005; Reci et al. 2011). In a study carried out by Ergintav et al. (2007) and Bonforte et al. (2007), the change in microgravity values at the same measurement points were examined together with vertical changes in GPS/GNSS data for determining the deformation in vertical direction in an investigation area. Additionally, using vertical velocities, tectonic structures were examined in some studies (Dietrich et al. 2004; Devoti et al. 2011). At present, studies have also been carried out on the subjects including monitoring geothermal reserves, groundwater levels, volcanic activities, determination of fault systems and mechanic connections of these systems, monitoring horstgraben areas and their stress deformation (Jentzsch et al. 2001; Battaglia et al. 2003; Carbone et al. 2003; Zeeuw-van Dalfsen et al. 2006). These types of relations show the vertical surface movements, also density and mass changes in the subsurface structures. From this point of view, GPS/GNSS and microgravity network system measurements were carried out together in Izmir and its surroundings (figure 1) in the complex tectonism of western Anatolian region for the scope of this study.

Western Anatolian region has a complex tectonism within an opening system in $\mathrm{N}-\mathrm{S}$ direction. Izmir and its surroundings are within this system as seen in figure 1(a). It is indicated in various approaches related to the tectonism belonging

Keywords. Izmir; microgravity; western Anatolia; GPS/GNSS; mass changes. 


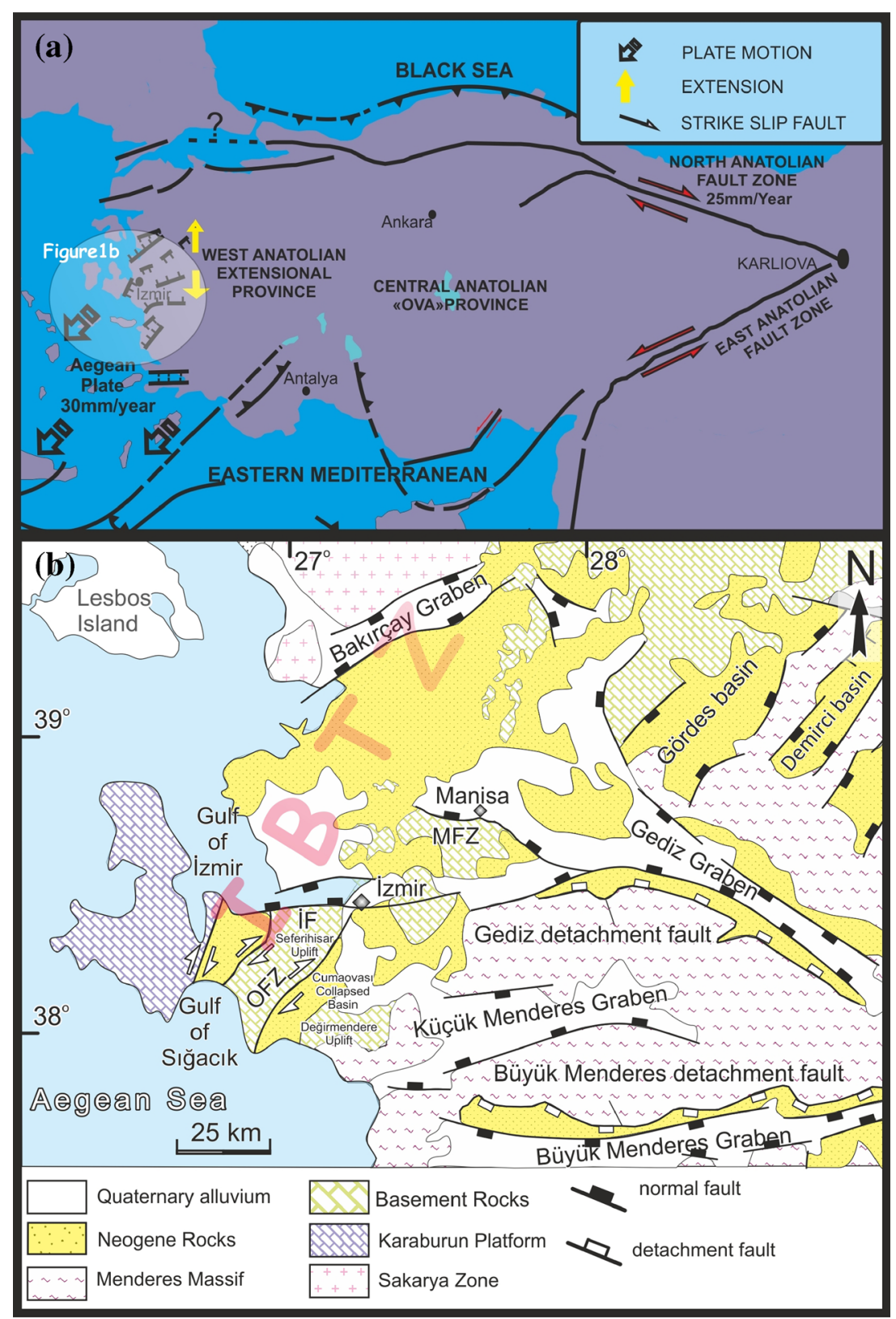

Figure 1. (a) The regional tectonic structure of the study area and (b) local tectonic elements of the study area (Dewey and Şengör 1979; Jackson and McKenzie 1984; Şengör et al. 1985; Eyidoğan and Jackson 1985; Şengör 1987; Ambraseys 1988; Seyitoğlu and Scott 1991; Taymaz et al. 1991; Reilinger et al. 1997; Ambraseys and Jackson 1998; Bozkurt 2001; Sözbilir 2001; Gönenç and Akgün 2011; Gonenç et al. 2012).

to Izmir and its surroundings (figure $1 b$ ) that the region is located in the corridor defined as IzmirBallkesir Transfer Zone (IBTZ) where strike-slip and normal faults exist together (Ocakoğlu et al. 2004, 2005; Uzel et al. 2010).

Maps of active faults known in Izmir and its surroundings were given by Şaroglu et al. (1992). However, it is indicated that there are more earthquake sources than known in the studies carried out in Izmir (Barka et al. 1996). At present, the new findings of the faults were pointed out by Emre et al. (2005) for the study area. In these studies, the necessity for resolving the kinematics of the faults formed in different directions within active tectonism, examining their kinematic characteristics in more detail, and carrying out more detailed investigations is indicated. The study of Nyst and Thatcher (2004) has pointed out that GPS/GNSS velocity vector directions have some differences in Izmir and its surroundings from western Anatolia. In the studies of Pamukçu et al. (2010a, b), the approaches were made for tectonic interpretation of gravity anomalies in Izmir and its surroundings.

Continuous visualization of the movements in the investigation area is an important point for understanding seismic risk of the region. From this 
point of view, microgravity and GPS/GNSS measurements (supported by Scientific and Technological Council of Turkey, 108Y285) were carried out between the years 2009 and 2011 in Izmir and its surroundings for/within the scope of this study.

As a result, statistical analyses of microgravity and GPS/GNSS measurements were carried out. The vertical changes of gravity data and vertical velocities which were obtained from GPS/GNSS data were evaluated together and finally individual datasets were examined by using seismological data of the investigation area.

\section{Applications}

The stations were built for GPS/GNSS and microgravity network system. Nineteen stations (figure 2) are on the bedrock, all of them are in the high topography zone and are built far away from faults to avoid near fault kinematic effects. The Trimble RTK 5700 for GPS/GNNS measurements and 2 pcs Scintrex gravimetry CG-5 for microgravity observation network were used (figure 3 ).

The plan for microgravity studies is given in figure 4. The six profiles were formed as 100, 200, 300, 400, 500, and 600 by using 19 measurement points (figure 5). IZMT is a base station and located inside Engineering Faculty, Tinaztepe Campus of Dokuz Eylül University. Profile intended directions are given with continuous lines in figure 5 .

In this study, the measurements at each microgravity point were measured as departure and return for two times (figure 4). This microgravity campaign was carried out across six separate profiles on approximately same dates between the years 2009, 2010, and 2011. The evaluation results of microgravity data are given in figure 6 .

GPS/GNNS measurements at each station were measured for 3 days and 10 hours for each day from the beginning of July for each year (2009-20102011). For processing GPS/GNSS data, the software, which is called GAMIT/GLOBK (Herring 2009; King and Bock 2009) was used. In figure 7, the results of vertical displacement by using ITRF2008 solutions are shown. In this step, ANKR, ISTA, TUBI (Turkey), ZECK (Russia), NSSP (Armenia), NICO (Cyprus), MIKL (Ukraine), GLSV (Ukraine), BUCU (Romania), PENC (Hungary), WTZR (Germany) and MATE (Italy) were evaluated as IGS (International GNSS Service) stations.

To this extent, microgravity data obtained in the field were processed by pre-data processing techniques. All the measurements were also assessed

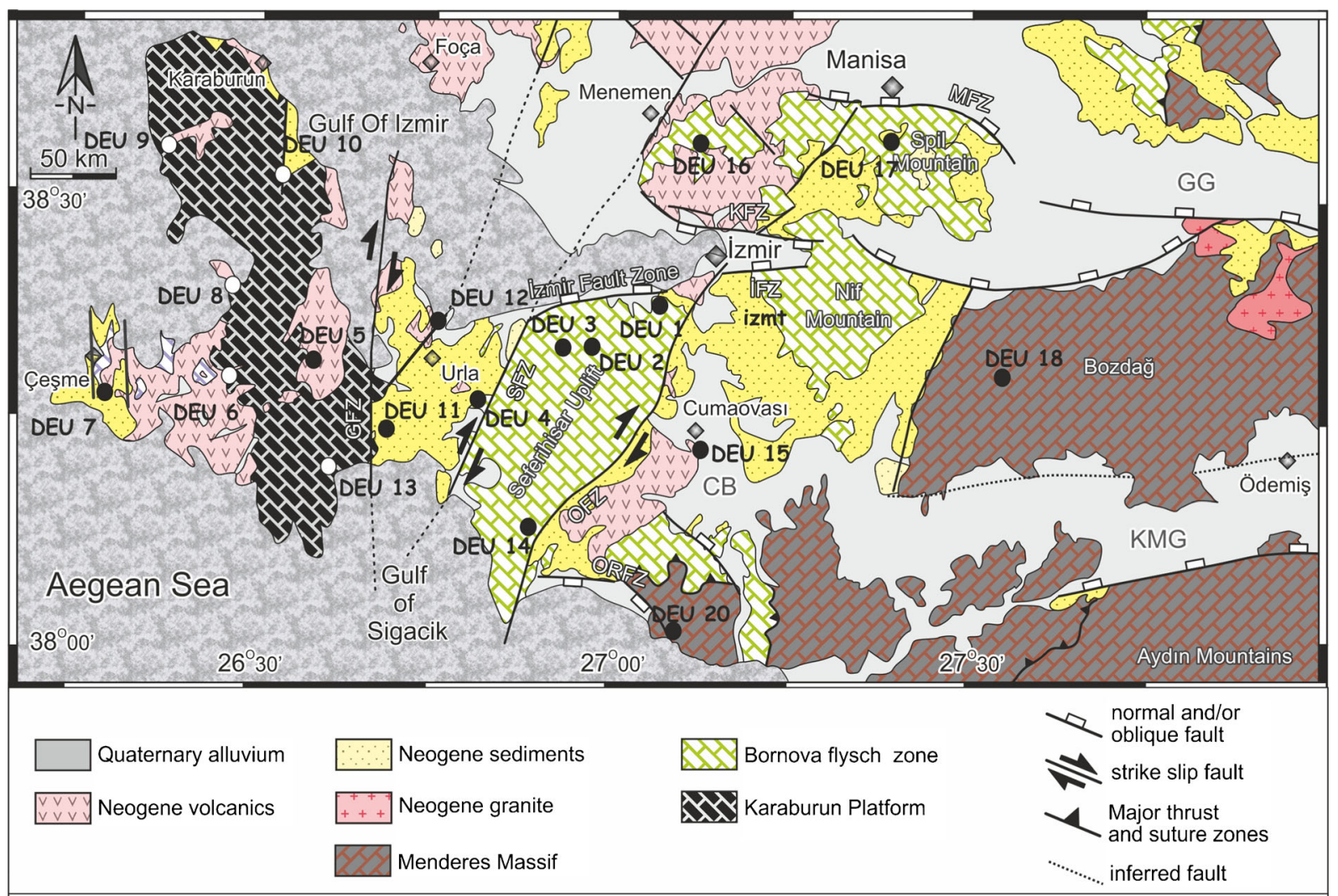

SFZ: Seferihisar Fault Zone, OFZ:Orhanlı Fault Zone, ORFZ:Ortaköy Fault zone, İFZ:Izmir Fault Zone, KFZ:Karşıyaka Fault Zone, MFZ:Manisa Fault Zone, GFZ:Gülbahçe Fault CB: Cumaovası Basin, GG:Gediz Graben, KMG: Küçük Menderes Graben 


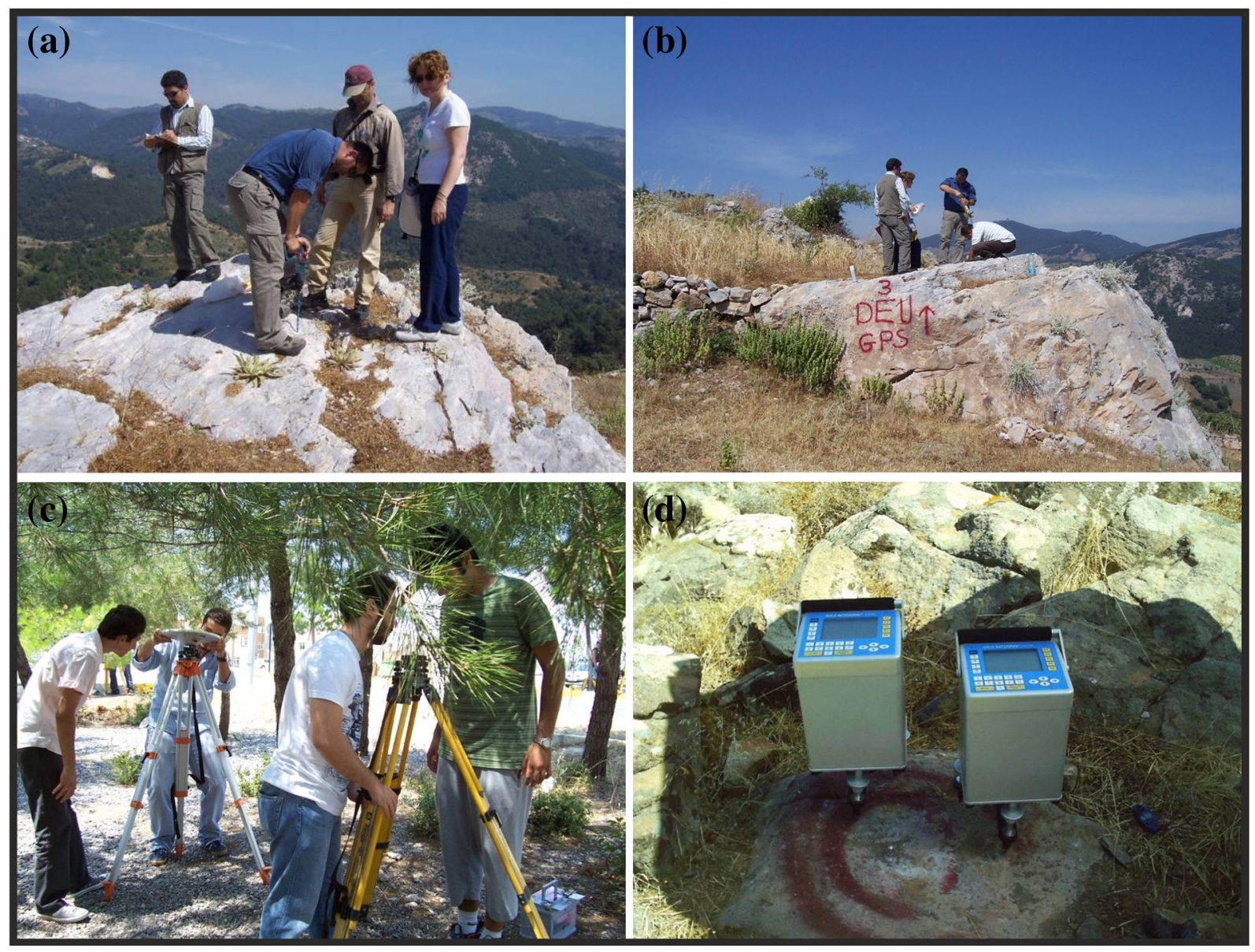

Figure 3. (a, b) One of the project stations when it is set up, (c) GPS/GNSS equipments, and (d) gravity equipments.

\begin{tabular}{|c|c|c|c|c|c|c|c|c|c|c|c|c|c|}
\hline Profiles & & & & & & & Stations & & & & & & \\
\hline 100 & Izmt & DEU14 & DEU11 & DEU13 & DEU5 & DEU10 & DEU5 & DEU13 & DEU11 & DEU14 & Izmt & & \\
\hline 200 & Izmt & DEU1 & DEU7 & DEU8 & DEU9 & DEU8 & DEU7 & DEU1 & Izmt & & & & \\
\hline 300 & Izmt & DEU2 & DEU3 & DEU12 & DEU4 & DEU11 & DEU14 & DEU11 & DEU4 & DEU12 & DEU3 & DEU2 & Izmt \\
\hline 400 & Izmt & DEU18 & DEU1 & DEU20 & DEU1 & DEU18 & Izmt & & & & & & \\
\hline 500 & Izmt & DEU1 & DEU16 & DEU17 & DEU16 & DEU1 & Izmt & & & & & & \\
\hline 600 & Izmt & DEU5 & DEU6 & DEU15 & DEU6 & DEU5 & Izmt & & & & & & \\
\hline
\end{tabular}

Figure 4. The study plan of microgravity mesurements, Izmt is base point.

by means of GravAP software (Schueler 2010). At first, instrument elevation, tide, atmosphere, drift and base corrections were applied by means of pressure, temperature, instrument elevation values. Approximately 15 repetitive measurements were carried out at each measurement point. The section remaining in drift \pm 8 range of the gravity values belonging to these measurements was selected. Subsequently, attention was paid for keeping the lowest and the highest values of standard 


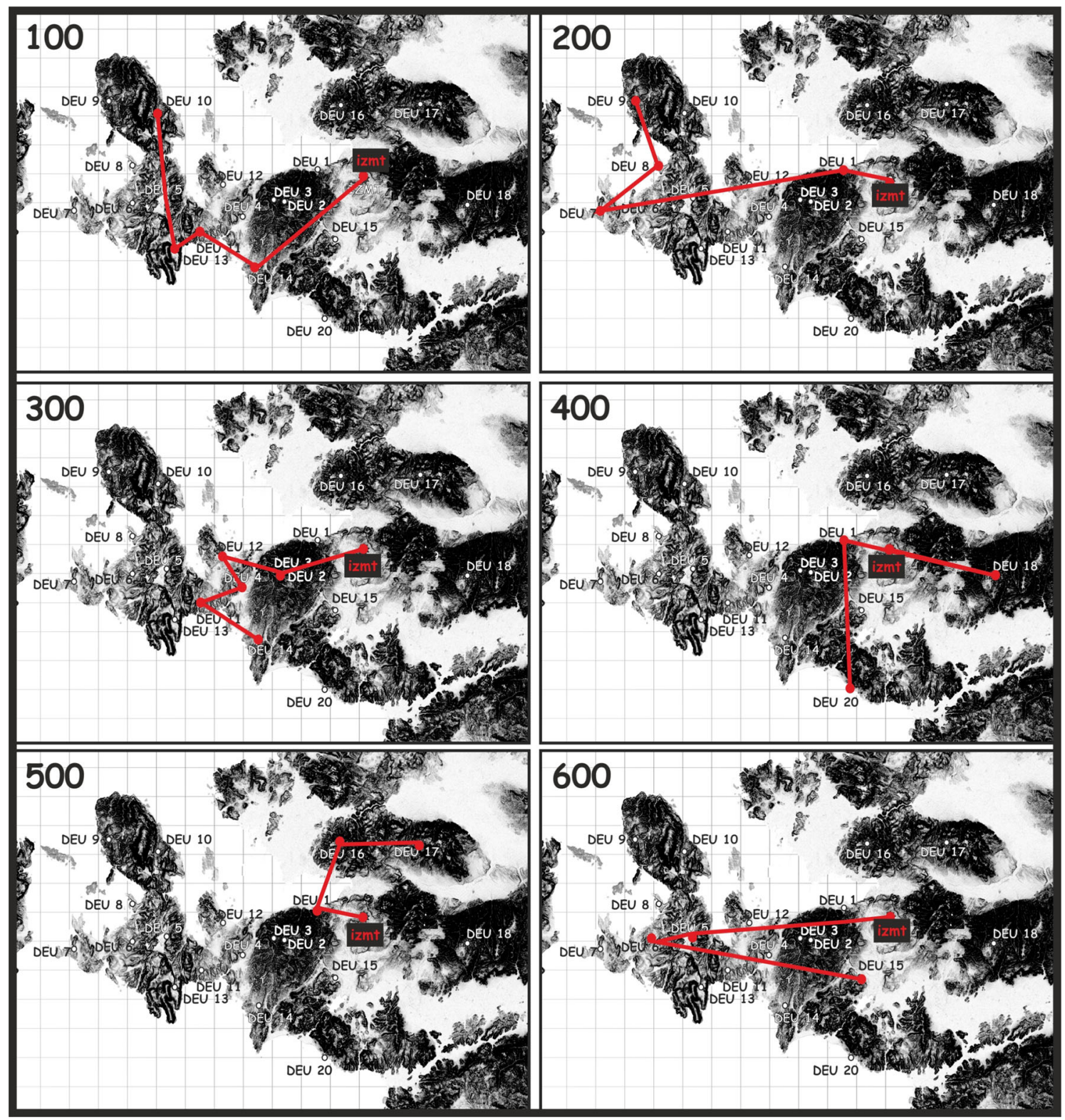

Figure 5. The microgravity stations and mesurement lines which are red in colour.

deviations of measured profiles within a security limit of $95 \%$.

Processing GPS and gravity data according to time (their increase/decrease relations) are worth considering to explain the deformation of station points. In this study, after processing the datasets, the statistical relations were investigated by correlation analyses. For this purpose, correlation coefficient ' $r$ ' was used. The values of $r$ are $-1 \leq$ $r \leq 1$. As it is known, if the correlation coefficient is positive while the value of one of the variables increases (or decreases), the other one increases (decreases). Conversely, if the coefficient is negative, while the value of one of the variables increases (or decreases) the other one decreases (increases). When $r=0$, it can be said that there is no linear relationship between the variables. If $r=+1$, there is a positive linear relationship between variables. If $r=-1$, it indicates a negative linear relationship.

Correlation coefficients calculated from gravity (figure 6) and GPS/GNSS (figure 7) measurement results are given in table 1 .

In the next step of the study, for obtaining gravity changes equation (1) was used.

$$
g\left(t_{k}\right)=g\left(t_{0}\right)+d g / d t\left(t_{k}-t_{0}\right) .
$$

Calculated gravity change results are given in table 2. Moreover, data given in table 2 were used for obtaining linear changes of gravity and vertical velocity (figure 11). 


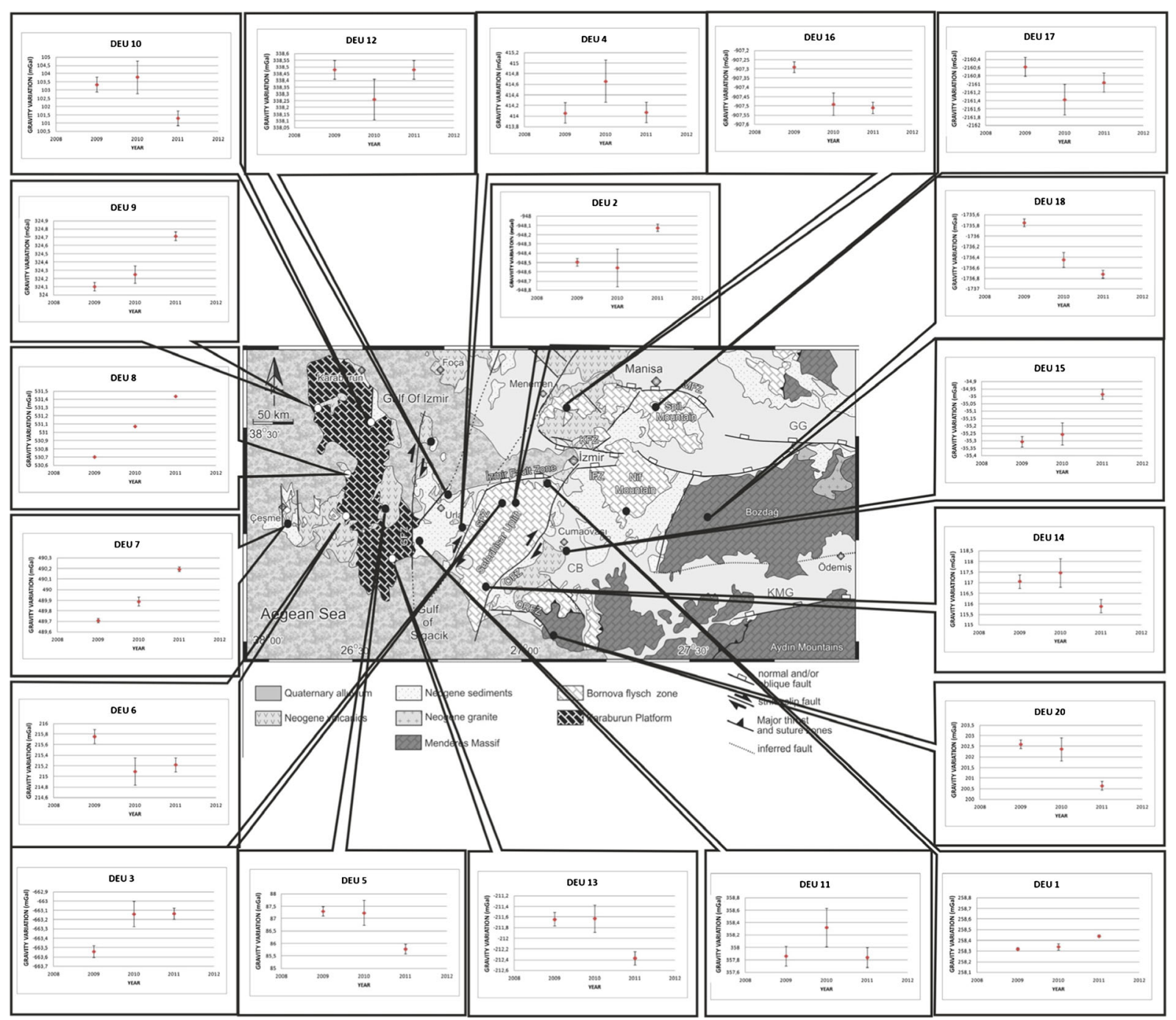

Figure 6. The microgravity measument values in 2009-2010-2011 and tectonic setting (figure 2) of the study area.

\section{Discussions and conclusions}

GPS/GNNS and microgravity network system was used to understand the behaviour of vertical displacement of the region and the active tectonism in southern Izmir, which is included within the western Anatolia extending system.

Results related to vertical displacement of time dependent microgravity and GPS/GNNS data between 2009 and 2011 years are presented in figures 6 and 7 . As can be seen from table 1, showing relations between two datasets, there are negative relations between DEU1, DEU2, DEU5, DEU6, DEU9, DEU11, DEU12, DEU14, DEU16, DEU17, DEU18, and DEU20. Thus they offered increased gravity value in response to decreased vertical changes or decreased microgravity value in response to increased vertical changes. But, in table 1 , the correlation coefficients of DEU2, DEU9, DEU16, DEU17, DEU20, besides being negative, were below -0.5 . This result shows that two variables may have a negative but nonlinear relation. The correlation coefficients of DEU3, DEU4, DEU7, DEU8, DEU10, DEU13, and DEU15 were positive (table 1). According to this result they offered increased (decreased) gravity value in response to increased (decreased) vertical changes. DEU10 also had a correlation coefficient below 0.5. This result may also be due to a positive but a nonlinear relation among variables of GPS/GNSS and gravity. DEU3, DEU4, DEU7, DEU8, DEU10, DEU13, DEU15 were not working in a manner suitable for isostatic balance. This may be possibly considered as imbalance in load distribution caused by subsurface mass loss due to geothermal environment, subsurface water or seismic activity for these points (Pamukçu et al. 2014a). According to isostasy theory, while vertical displacement is negative (-), gravity value should be positive (Watts 2001). To investigate the effects of surface load on these points, gravity changes data given in figure 11(a) and topographic map 


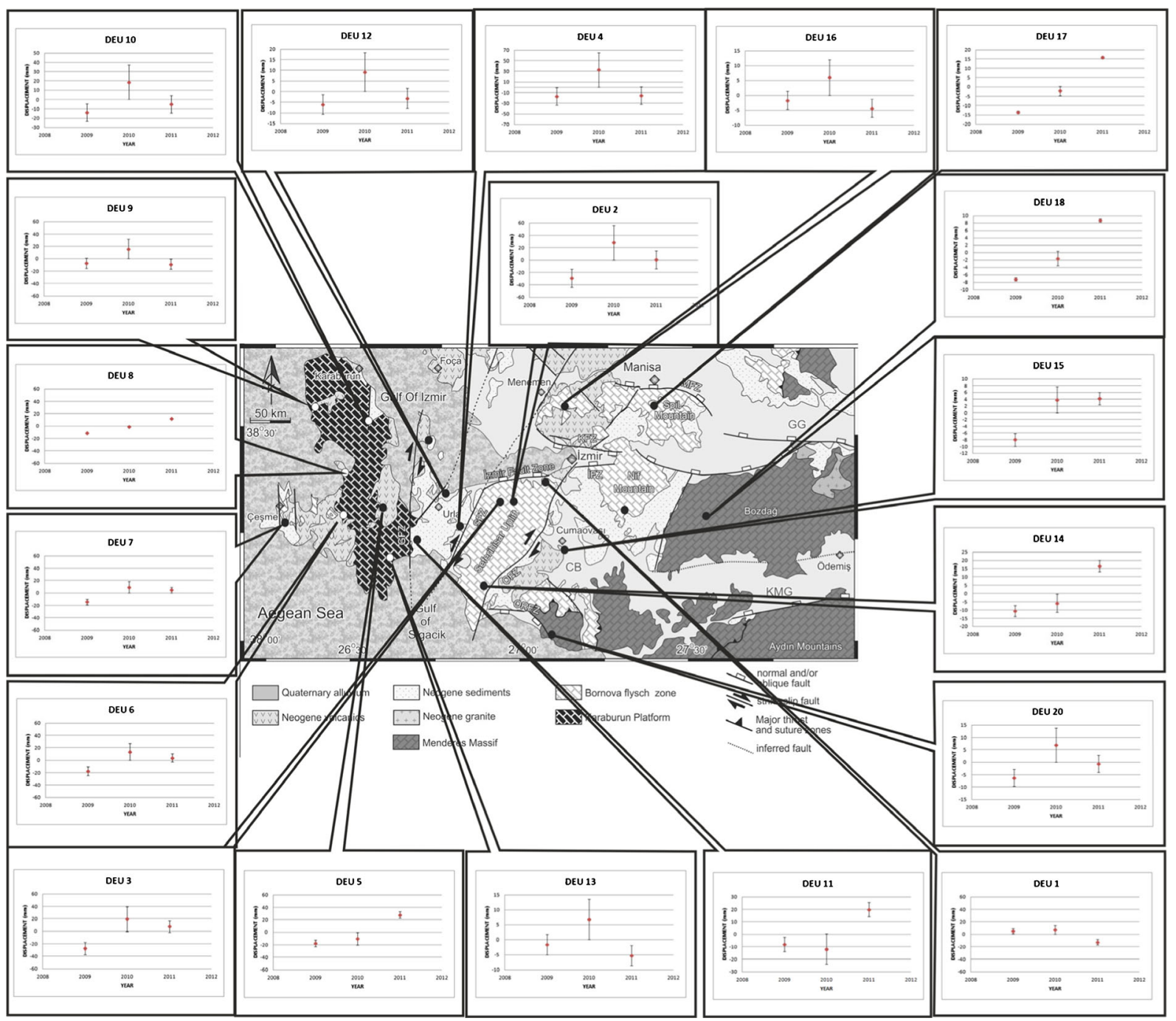

Figure 7. The GPS/GNSS vertical displacement values in 2009-2010-2011 and tectonic setting (figure 2) of the study area.

Table 1. Correlation coefficients of GPS/ GNSS and gravity measurement results.

\begin{tabular}{lr}
\hline Station name & \multicolumn{1}{c}{$r$} \\
\hline DEU 1 & -0.963975585 \\
DEU 2 & -0.107272114 \\
DEU 3 & 0.966267299 \\
DEU 4 & 0.999962112 \\
DEU 5 & -0.992849122 \\
DEU 6 & -0.990940172 \\
DEU 7 & 0.666490719 \\
DEU 8 & 0.994229705 \\
DEU 9 & -0.340666125 \\
DEU 10 & 0.412529893 \\
DEU 11 & -0.618333974 \\
DEU 12 & -0.984108589 \\
DEU 13 & 0.749763187 \\
DEU 14 & -0.916409483 \\
DEU 15 & 0.642297519 \\
DEU 16 & -0.190825629 \\
DEU 17 & -0.367337167 \\
DEU 18 & -0.914612737 \\
DEU 20 & -0.022538063
\end{tabular}

Table 2. Obtained $d g / d t$ values of measured microgravity values.

\begin{tabular}{lcl}
\hline Station Id & $\mathrm{dg} / \mathrm{dt}$ & RMS (\%) \\
\hline DEU 1 & 0.06 & \pm 0.019149 \\
DEU 2 & 0.185 & \pm 0.12278 \\
DEU 3 & 0.2025 & \pm 0.093162 \\
DEU 4 & 0.005 & \pm 0.280505 \\
DEU 5 & -0.7575 & \pm 0.33187 \\
DEU 6 & 0.2675 & \pm 0.1827 \\
DEU 7 & 0.2425 & \pm 0.029463 \\
DEU 8 & 0.3675 & \pm 0.003536 \\
DEU 9 & 0.3075 & \pm 0.074246 \\
DEU 10 & -1.0225 & \pm 0.685447 \\
DEU 11 & -0.01 & \pm 0.221585 \\
DEU 12 & 0.001 & \pm 0.103763 \\
DEU 13 & -0.365 & \pm 0.179141 \\
DEU 14 & -0.58 & \pm 0.464408 \\
DEU 15 & 0.16 & \pm 0.051881 \\
DEU 16 & -0.11 & \pm 0.042426 \\
DEU 17 & -0.19 & \pm 0.284429 \\
DEU 18 & -0.48754 & \pm 0.100187 \\
DEU 20 & -0.9775 & \pm 0.355452 \\
\hline
\end{tabular}


given in figure 8 were evaluated together. As a result, while topographic value of DEU3 is high, its gravity change is also high. This result shows that the expectation about negative gravity changes of higher topographic measurement points and positive gravity changes of lower topographic measurement points is not confirmed for all stations. It can be concluded that effects of surface loads on time dependent gravity changes may not be significant.

It is accepted that some structures and formations are developed during and after the earthquake (Audemard and De Santis 1991) and they are examined under two main classes as seismotectonic and seismogravitational (Dramis and Blumetti 2005). Seismotectonic structures are the deformations developed depending on tectonic stresses, and in form of faults, horst-graben systems, geothermal areas, and longitudinal ridges. However, seismogravitational structures are the deformations caused by mass displacement, micro fissures, and liquefaction. It is known that earthquakes forming the deformations have occurred

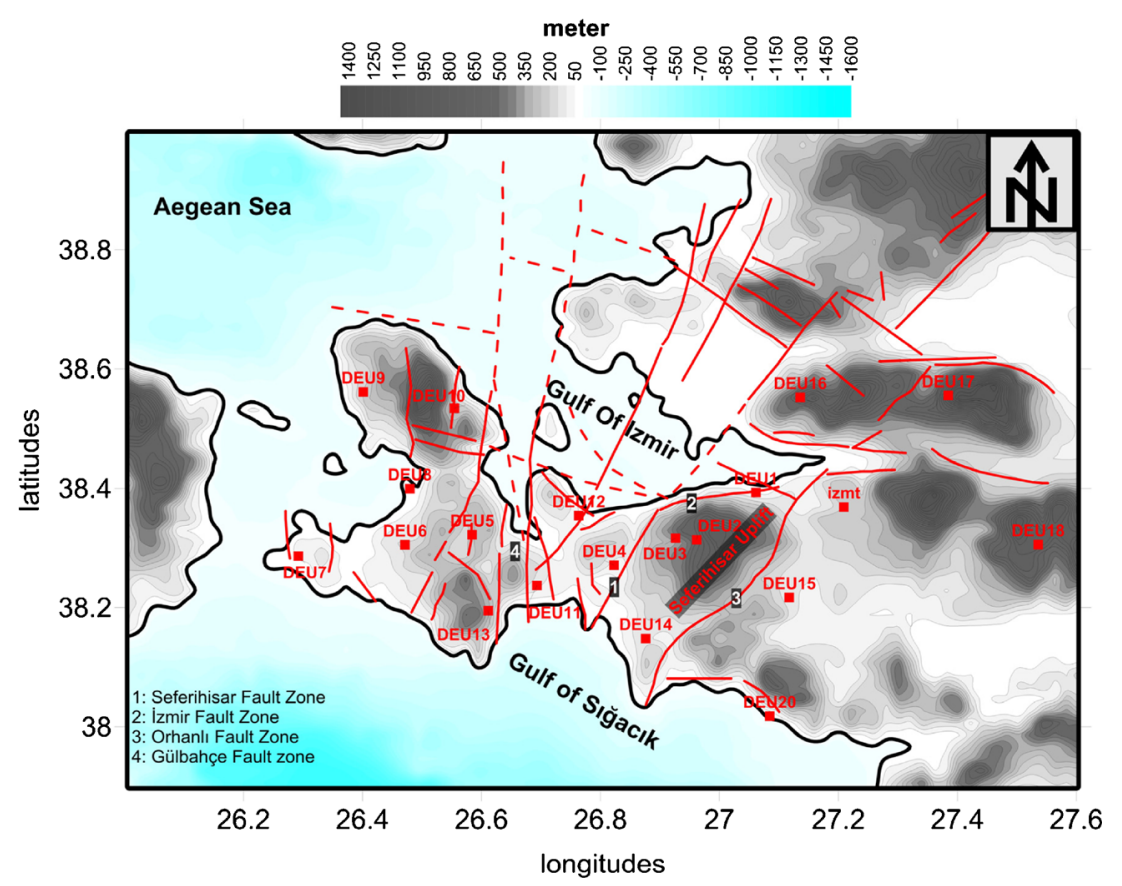

Figure 8. Topographic map and main tectonic structures of the study area (Kaya 1979; MTA 2002; Uzel et al. 2012; Pamukcu et al. 2014b).

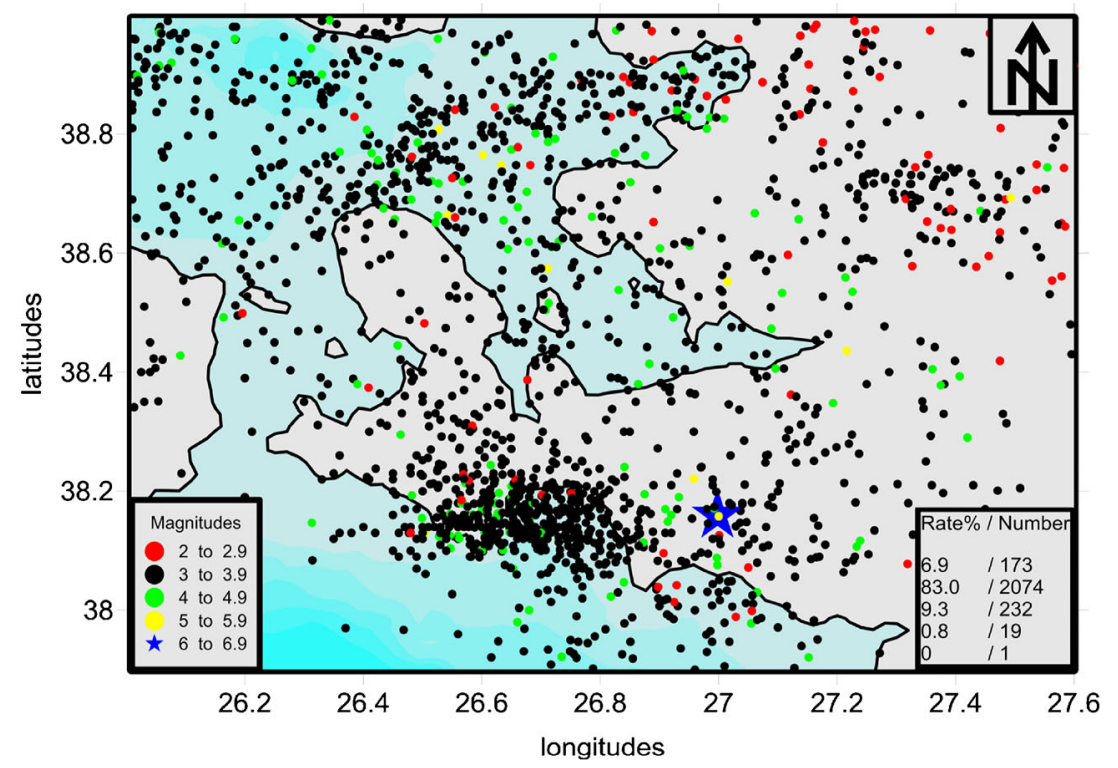

Figure 9. The magnitude distrubution of the earthquakes between 1970 and 2012 in Izmir. 
since historical period until today in western Anatolia and especially in Izmir and its surroundings, where the inspection area is located. So, the measured data were evaluated in the light of seismologic data of the region. Primarily, the distribution of the earthquakes with magnitudes varying between 2 and 6.9 (figure 9) and depths of focus varying between 2 and $40 \mathrm{~km}$ (figure 10) obtained from USGS (US Geological Survey) between the dates 1970 and 2012 are given. When figures 9, 10, and 11 were evaluated together, on the southwest of the study area, Gulf of Siğacık, high seismic activity, negative gravity change, and positive vertical velocity (except for DEU13) were determined. It is thought that a structure causing earthquakes having magnitude of 3-4 (figure 9) and focus depth of 10-20 km (figure 10) may be effective on tectonic mechanism of the region, which may also affect vertical velocity and gravity changes.

Microgravity changes of 3 years which are compiled in table 2 and vertical velocities obtained from GPS/GNSS values of 3 years (error-rate tolerances are $\pm 10 \mathrm{~mm}$ ) and earthquake focus distributions are given in figure 11 . When the gravity changes in figure 11(a) are examined, a north-south directional structure is observed. An increase in gravity changes of DEU6, DEU7, DEU8, DEU9 located on the west side of the north-south directional structure is observed and DEU5, DEU10, and DEU13 located on the east side of this structure have lower gravity changes. This situation partially confirms topographic changes given in figure 8. On the other hand, although topography of DEU5 is closer to sea level than DEU10 and DEU13, its gravity change is negative (figures 8 and 11a). Although in the east side of the study area,
Seferihisar Uplift, there is an increase in gravity changes of DEU1, DEU2, DEU3, and DEU15 measurement points; in the south part of that area, DEU14 and DEU20 have lower values when compared to the north. Results of this area are also roughly in parallel with the topographic data given in figure 8. But topographic value of DEU1 and gravity change when compared to DEU2, DEU3, and DEU15 show positive changes around Seferihisar Uplift. From the same point of view, gravity change of DEU20 is negative like DEU14, although it is closer to sea level.

In figure 11(b), changes in vertical velocities have a repeat of high in positive trend and high in negative trend in west-east direction. Vertical velocity changes from west to east are: high in positive trend for DEU6, DEU7, DEU8, DEU5, DEU11 measurement points (uplift), stable for DEU12 and DEU4, high in positive trend for DEU1, DEU2, DEU15 (uplift) and high in negative trend for DEU1 and DEU16 (collapsed).

When figure 11(a and b) are compared, parallel to the positive increase in gravity changes of DEU6, DEU7, and DEU8 measurement points, vertical velocity changes are positive. The same situation is valid for DEU3, DEU2, and DEU15. Besides these, vertical velocities and gravity changes of DEU16 measurement points have negative values. Although gravity changes of DEU5, DEU10, DEU14, DEU17, DEU18, DEU20 measurement points are negative, their vertical velocities are positive. Vertical velocity of DEU9 is stable and its gravity change is positive. Vertical velocity of DEU1 is negative and its gravity change is positive. No significant changes were observed for DEU12 and DEU4 for an observation period of 3 years.

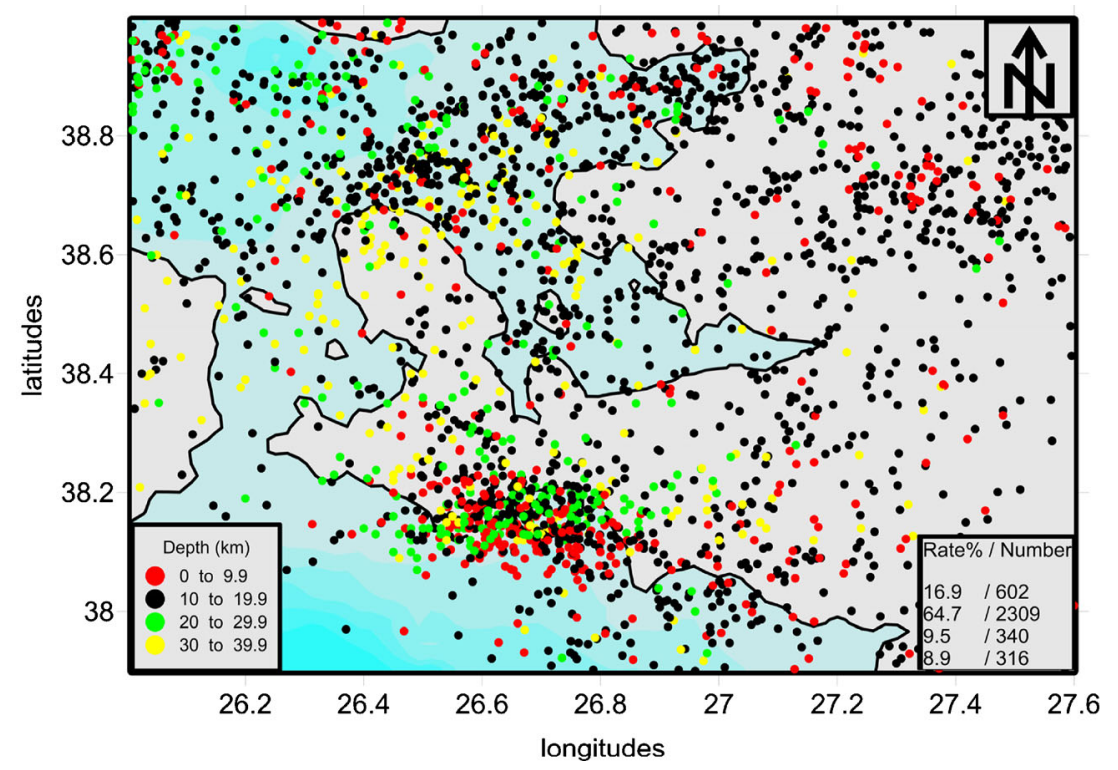

Figure 10. The earthquakes focus depth distrubution between 1970 and 2012 in Izmir. 

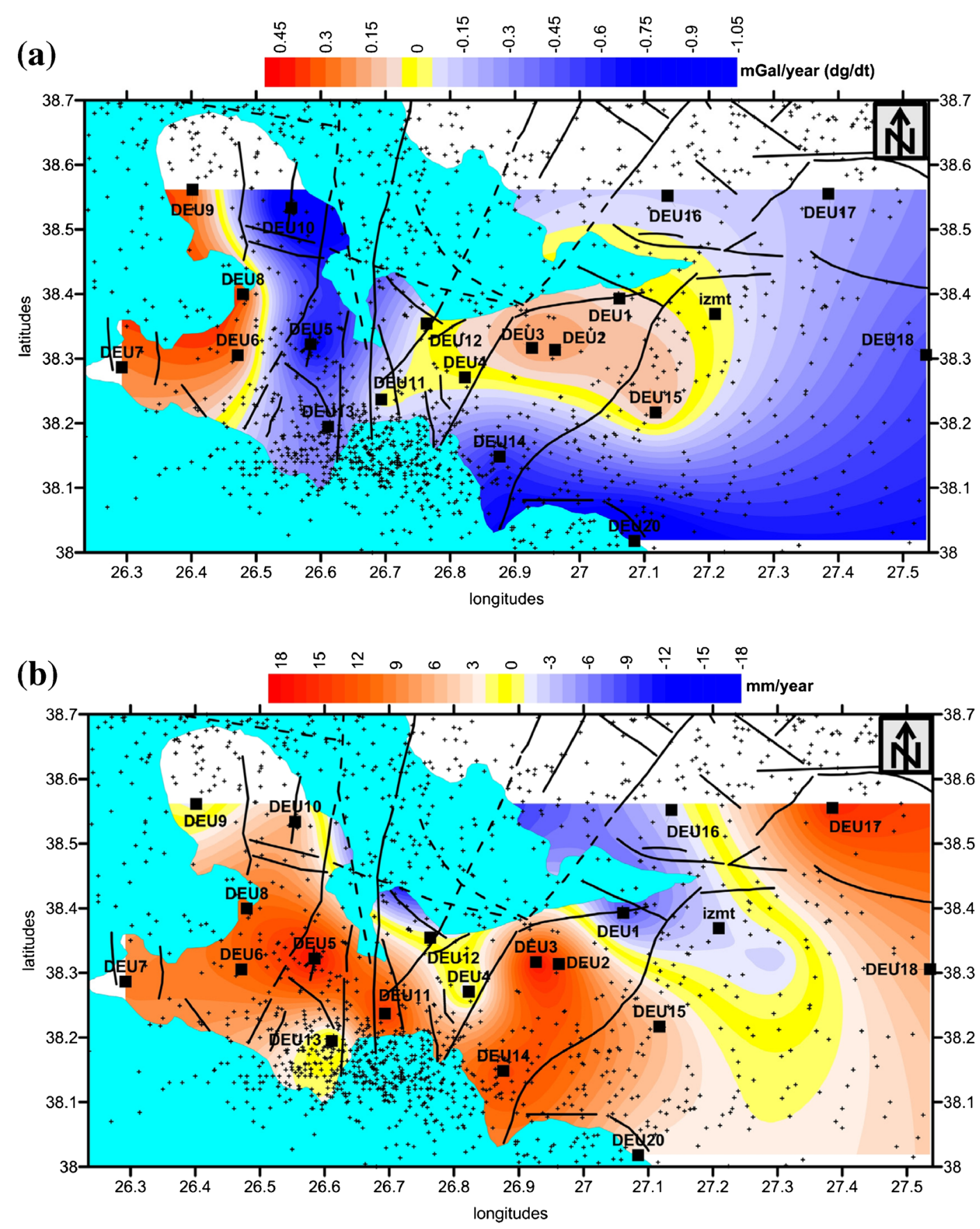

Figure 11. Main tectonic faults, earthquakes focus depth distrubution between 1970-2012 and (a) dg/dt map of gravity values and (b) vertical velocity map of Izmir.

Interesting results were obtained for DEU11 and DEU13, which are located at a region where seismic activity is high (figures 9, 10). Although vertical velocity of DEU13 is lower than the other stations, its gravity change is negative for 3 years of observation. This situation can be evaluated as a result of subsurface density/mass loss, collapse, geothermal effects, and seismic gaps, etc., in the region. For 3 years, DEU11 has shown no gravity changes but high vertical velocity in positive direction. This result can be attributed to the void within the structure. In conclusion, this region should be investigated thoroughly.

\section{Acknowledgements}

This study has been achieved under the scope of No. 108Y285, The Scientific and Technological Research Council of Turkey (TÜBİTAK) project. Authors wish to acknowledge Dokuz Eylul University Earthquake Research and Exploration Centre 
and would like to thank The Scientific and Technological Research Council of Turkey, Marmara Research Center and Prof. Haluk Özener from Boğaziçi University, Assist. Prof. Osman Uyanık and Geophysical Engineer Olcay Çakmak from Isparta University for the equipment support and also Assoc. Prof. Muzaffer Kahveci, Prof. Hasan Sözbilir as Project advisors, Prof. Thomas Herring for his assistance in Gamit/Globk software and Geophysical Engineer Mehmet Çetiner in field surveys. Also they thank the reviewer and $\mathrm{N} \mathrm{V}$ Chalapathi Rao (Associate Editor, Journal of Earth System Science) for improving the paper.

\section{References}

Ambraseys N N 1988 Engineering seismology; Earthq. Eng. Struct. Dyn. 17 1-105.

Ambraseys N N and Jackson J A 1998 Faulting associated with historical and recent earthquakes in the eastern Mediterranean region; Geophys. J. Int. 133 390-406.

Audemard F A and De Santis F 1991 Survey of liquefaction structures induced by recent moderate earthquakes; Bull. Int. Assoc. Eng. Geol. 44 5-16.

Barka A A, Şaroğlu F, Emre Ö and Kuşçu İ 1996 Active faults of Turkey; J. Earthq. Prediction Res. 5(3) 413-421.

Battaglia M, Segall P and Roberts C 2003 The mechanics of unrest at Long Valley caldera, California. 2. Constraining the nature of the source using geodetic and micro-gravity data; J. Volca. Geoth. Res. 127 219-245.

Bonforte A, Carbone D, Greco F and Palano M 2007 Intrusive mechanism of the 2002 NE-rift eruption at Mt Etna, Italy modelled using GPS and gravity data; Geophys. J. Int. $169339-347$.

Bozkurt E 2001 Neotectonics of Turkey - a synthesis; Geodinamica Acta 14 3-30.

Butler K D 1984 Microgravimetric and gravity gradient techniques for detection of subsurface cavities; Geophysics $\mathbf{4 9}$ 1084-1096.

Carbone D, Budetta G and Greco F 2003 Possible mechanisms of magma redistribution under Mt Etna during the 1994-1999 period detected through microgravity measurements; Geophys. J. Int. 153 187-200.

Devoti R, Esposito A, Pietrantonio G, Pisani A R and Riguzzi F 2011 Evidence of large scale deformation patterns from GPS data in the Italian subduction boundary; Earth Planet. Sci. Lett. 311 230-241.

Dewey J F and Şengör A M C 1979 Aegean and surrounding regions: Complex multi-plate and continuum tectonics in a convergent zone; Bull. Seismol. Soc. Am. 90 84-92.

Dietrich R, Rülke A, Ihde J, Lindner K, Miller H, Niemeier W, Schenke H W and Seeber G 2004 Plate kinematics and deformation status of the Antarctic peninsula based on GPS; Global Planet. Change 42 313-321.

Dramis F and Blumetti A M 2005 Some considerations concerning seismic geomorphology and paleoseismology; Tectonophys. 408 177-191.

Emre Ö, Özalp S, Doğan A, Özaksoy V, Yıldırım C and Göktaş F 2005 Active faults and earthquake potential of İzmir and surroundings (in Turkish); General Directorate of Mineral Research MTA, Rpt. No. 10754, pp. 1-80.

Ergintav S, Doğan U, Gerstenecker C, Çakmak R, Belgen A, Demirel H, Aydin C and Reilinger R 2007 A snapshot 2003-2005 of the 3D post-seismic deformation for the $1999, \mathrm{M}_{\mathrm{w}}=7.4$ Izmit earthquake in the Marmara Region, Turkey, by first results of joint gravity and GPS monitoring; J. Geodesy 44 1-18.

Eyidoğan H and Jackson J A 1985 A seismological study of normal faulting in the Demirci, Alaşehir and Gediz earthquake of 1969-1970 in western Turkey: Implications for the nature and geometry of deformation in the continental crust; Geophys. J. Roy. Astron. Soc. 81 569-607.

Gönenç T and Akgün M 2011 Structure of the hellenic subduction zone from gravity gradient functions and seismology; Pure Appl. Geophys. 169 1231-1255.

Gonenç T, Pamukcu O, Pamukcu C and Deliormanli A H 2012 The investigation of hot spots in western Anatolia by geophysical and mining approaches; Energy Sources Part A 34 775-792.

Herring T A 2009 GLOBK: Global Kalman Fitler VLBI and GPS analysis program 10.3. MIT, Cambridge.

Ioane D and Ion D A 2005 3D crustal gravity modelling of the Romanian Territory; J. Balkan Geophys. Soc. 8 189-198.

Jackson J A and McKenzie D P 1984 Active tectonics of the Alpine-Himalayan Belt between western Turkey and Pakistan; Geophys. J. Roy. Astron. Soc. 7 185-264.

Jentzsch G, Punongbayan R S, Schreiber U, Seeber G, Völksen C and Weise A 2001 Mayon volcano, Philippines: Change of monitoring strategy after microgravity and GPS measurements from 1992 to 1996; J. Vol. Geoth. Res. 109 219-234.

Kaya O 1979 The stratigraphy and tectonics of the middle eastern Aegean depression "Ortadoğu Ege çöküntüsünün Neojen stratigrafisi ve tektoniği, Türkiye Jeoloji Kurumu Bülteni"; Bull. Geol. Soc. Turkey 22 35-58.

King R W and Bock Y 2009 Documentation for the GAMIT Analysis Software, Release 10.3. MIT, Cambridge.

MTA Mineral Research \& Exploration General Directorate 2002 1/500,000 scaled geological maps of Turkey, No. 7, MTA archives.

Nyst M and Thatcher W 2004 New constraints on the active tectonic deformation of the Aegean; J. Geophys. Res. 109 B11406/1-23.

Ocakoğlu N, Demirağ E and Kuşcu İ 2004 Neotectonic structures in the area offshore of Alaçatı, Doğanbey and Kuşadası, western Turkey: Evidence of strike-slip faulting in the Aegean extensional province; Tectonophys. 391 67-83.

Ocakoğlu N, Demirağ E and Kuşcu İ 2005 Neotectonic structures in Izmir Gulf and surrounding regions western Turkey: Evidences of strike-slip faulting with compression in the Aegean extensional regime; Marine Geol. 219 $155-171$.

Pamukçu O, Kahveci M, Ersay E Y, Yurdakul A, Şalk M and Sözbilir H 2010a Determination of the kinematic structure of Izmir and surroundings using repeated GPS/GNSS observations: Preliminary Results, 15th General Assembly of Wegener, Istanbul, Turkey.

Pamukçu O, Yurdakul A, Kahveci M, Şalk M, Gönenç T, Ersay E, Ergintav S and Belgen A 2010b Evaluation of microgravity and GPS/GNSS data together by the network system and a case study in İzmir, western Turkey; 10th International Multidisciplinary Scientific Geoconference SGEM 2010, Bulgaria, SGEM 2010 Conference Proceedings, I 777-782.

Pamukçu O, Gönenç T, Uyanık O, Sözbilir H and Çakmak O 2014a A microgravity model for the city of Izmir western Anatolia and its tectonic implementations, Acta Geophysica, doi: 10.2478/s11600-014-0203-z.

Pamukçu O, Gönenç T, Sındırgı P and Baba A 2014b Application of geophysical methods in Gulbahce geothermal 
site, Urla-Izmir, western Anatolia, Geothermal Systems and Energy Resources: Turkey and Greece Sustainable Energy Developments, 978-1138001091, CRC Press, pp. 251-257.

Reci H, Tsokas G N, Papazachos C and Bushat S 2011 Conversion of Bouguer gravity data to depth, dip and density contrast with complex attributes analysis technique, in the area of Greece; Roman. Rep. Phys. 63 302-320.

Reilinger R E, McClusky S C, Oral M B, King W and Toksöz M N 1997 Global positioning system measurements of present-day crustal movements in the Arabian-AfricaEurasia plate collision zone; J. Geophys. Res. 102 99839999.

Şaroglu F, Emre O and Kuscu I 1992 Active Fault Map of Turkey, General Directorate of Mineral Research and Exploration MTA, Eskisehir Yolu, 06520, Ankara, Turkey.

Schueler T 2010 GSS/INS Laboratory; http://www.ifen. unibw-muenchen.de/software/gravap/index.htm.

Şengör A M C 1987 Cross-faults and differential stretching of hanging walls in regions of low-angle normal faulting: Examples from western Turkey; In: Continental Extensional Tectonics (eds) Coward M P, Dewey J F and Hancock P L, Geol. Soc. London, Spec. Publ. 28 575-589.

Şengör A M C, Görür N and Şaroğlu F 1985 Strike-slip faulting and related basin formation in zones of tectonic escape: Turkey as a case study; In: Strike-slip
Deformation, Basin Formation and Sedimentation (eds) Biddle K and Christie-Blick N, Soc. Econ. Paleontol. Mineral. Spec. Publ. 37 227-264.

Seyitoğlu G and Scott B C 1991 Late Cenozoic extension and basin formation in west Turkey; Geol. Mag. 128 $155-166$.

Sözbilir H 2001 Extensional tectonics and geometry of related macroscopic structures: Field evidence from the Gediz detachment, western Turkey; Turkish J. Earth Sci. 10 51-67.

Taymaz T, Jackson J and McKenzie D 1991 Active tectonics of the north and central Aegean Sea; Geophys. J. Int. 106 433-490.

Uzel B, Sözbilir H and Özkaymak Ç 2010 Neotectonic evolution of an actively growing superimposed basin in western Anatolia: The inner bay of Izmir, Turkey; Turkish J. Earth Sci. 21 439-471.

Uzel B, Sözbilir H and Özkaymak Ç 2012 Neotectonic evolution of an actively growing superimposed basin in western Anatolia: The Inner Bay of Izmir, Turkey; Turk. J. Earth Sci. 21(4) 439-471.

Watts A B 2001 Isostasy and Flexure of the Lithosphere; England, Cambridge University Press, pp. 87-283.

Zeeuw-van Dalfsen E, Hazel R, Williams-Jones G, Sturkell E and Sigmundsson F 2006 Integration of micro-gravity and geodetic data to constrain shallow system mass changes at Krafla Volcano, N Iceland; Bull. Volcanol. 68 420-431. 